\title{
UPAYA PENINGKATAN HASIL BELAJAR PENDIDIKAN AGAMA ISLAM MENGGUNAKAN COOPERATIVE LEARNING TIPE STUDENTS TEAM ACHIEVEMENT DIVISION (STAD)
}

\author{
M. Agus Salim \\ STKIP Kumala Lampung Metro \\ agusms@kumala.ac.id
}

\begin{abstract}
This study is intended to examine efforts to improve student learning outcomes using the STAD type cooperative strategy given the low absorption of students in learning as well as one method for teachers to improve student learning outcomes in schools. Cooperative learning strategies are one way to strive for student activities in learning so that they are involved cognitively and psychomotor in them. But the extent to which this cooperative learning strategy contributes to student learning success compared to the expository strategy needs to be empirically proven. The research method that will be used is Classroom Action Research (CAR)wbich aims to improve the learning process. The results of this study indicate that learning using cooperative strategies gradually increases from cycle I, II and III with the final percentage score of 88.39. While the implementation of $P A I$ learning using cooperative strategy media also went well, in this case there was an increase in teacher activity during the learning process from cycle I to cycle II, and cycle III. The acquisition of $\mathrm{PAI}$ learning achievement increases along with the improvement of learning planning, implementation of learning, and the implementation of evaluation of learning using cooperative strategies.
\end{abstract}

Keywords: Cooperative Strategy, Cooperative STAD, Learning Outcomes, Islamic Education.

Nazhruna: Jurnal Pendidikan Islam

Vol. 2 No 1 2019. Issn: 2614-8013. Hal. 45-67

DOI: $10.3153 /$ nzh.v2i1.197 


\section{Abstrak}

Penelitian ini dimaksudkan untuk mengkaji upaya peningkatan hasil belajar siswa dengan menggunakan strategi kooperatif tipe STAD mengingat masih rendahnya daya serap peserta didik dalam pembelajaran sekaligus sebagai salah satu metode bagi guru untuk meningkatkan hasil belajar siswa disekolah. Strategi pembelajaran kooperatif merupakan salah satu cara untuk mengupayakan aktivitas siswa dalam pembelajaran sehingga terlibat secara kognitif, afektif dan psikomotorik di dalamnya. Namun Sejauh mana strategi pembelajaran kooperatif ini memberikan kontribusi terhadap keberhasilan belajar siswa dibandingkan dengan strategi ekspositoris perlu dibuktikan secara empiris. Metode penelitian yang akan digunakan adalah Penelitian Tindakan Kelas (PTK) yang bertujuan untuk melakukan perbaikan proses pembelajaran. Hasil Penelitian ini menunjukkan Pembelajaran menggunakan strategi kooperatif mengalami peningkatan secara bertahap dari siklus I, II dan III dengan peresentase skor terakhir adalah 88,39. Sementara pelaksanaan pembelajaran PAI dengan menggunakan media strategi kooperatif juga berjalan dengan baik, dalam hal ini terdapat peningkatan aktivitas guru selama proses pembelajaran dari siklus I ke siklus II, maupun siklus III. Perolehan prestasi belajar PAI meningkat seiring dengan peningkatan perencanaan pembelajaran, pelaksanaan pembelajaran, dan pelaksanaan evaluasi pembelajaran dengan menggunakan strategi kooperatif.

Kata Kunci: Strategi Kooperatif, Kooperatif STAD, Hasil Belajar, Pendidikan Agama Islam.

\section{Pendahuluan}

Rendahnya daya serap peserta didik dalam belajar menjadi salah satu permasalahan bagi para pelaku pendidikan formal maupun non formal di Indonesia. Terlihat dengan dominannya para guru dalam memberikan materi pelajaran masih menggunakan Konsep Teacher Centered. Sebagai fasilitator, para guru dituntut untuk mendesain pembelajaran dengan kreatif dan inovatif dimana seharusnya para guru tersebut dapat membuat siswa untuk aktif dan 
kreatif sehingga dalam prosesnya guru dapat memudahkan proses pencarian pengetahuan dari siswa.

Berdasarkan Kasus-kasus yang banyak terjadi, dapat dipahami bahwa pendidik selama ini hanya meraba-raba otak peserta didik yang kemudian diubahnya secara semena-mena. Konsekuensi yang tidak dapat dihindari adalah melesatnya tujuan pendidikan (optimalisasi potensi/kecerdasan) sehingga banyak peserta didik yang gagal mengarungi samudra kehidupan. Jika terdapat peserta didik yang berhasil, sebagian besar dari mereka bukan by design atau produk pendidikan semata, tetapi lebih karena by accident atau pembelajaran secara otodidak. ${ }^{1}$

Pembelajaran dalam suatu definisi dipandang sebagai upaya memengaruhi siswa agar belajar. Atau secara singkat dapat dikatakan bahwa pembelajaran sebagai upaya membelajarakan siswa. Akibat yang mungkin tampak dari tindakan pembelajaran adalah siswa akan (1) belajar sesuatu yang tidak akan mereka pelajari tanpa adanya tindakan pembelajar, atau (2) memelajari sesuatu dengan cara yang lebih efisien.

Proses belajar sebagai pengait pengetahuan baru pada struktur kognitif yang sudah dimiliki siswa. Pengaitan-pengaitan ini akan membentuk struktur kognitif baru yang lebih mantap, yang dapat dipandang sebagai hasil belajar. Konsepsi ini akan menjadi pijakan dalam identifikasi dan pengembangan strategi pembelajaran. ${ }^{2}$

Upaya memperbaiki proses pembelajaran tersebut diperlukan berbagai model pembelajaran yang sesuai dengan kondisi pembelajaran. Maksud dengan kondisi pembelajaran di sini adalah tujuan bidang studi, kendala bidang studi dan karakteristik siswa. Biasanya karakteristik bidang studi dan karakteristik siswa yang berbeda memerlukan model pembelajaran yang berbeda pula. ${ }^{3}$ Upaya mengkondisikan para siswa agar selalu menjadi aktif dalam setiap proses pembelajaran dengan belajar secara kelompok di

1 Suyadi, 2015, Teori Pembelajaran Anak Usia Dini dalam Kajian Neurosains, Bandung. Pt. Remaja Rosdakarya, Hal. 2

${ }^{2}$ Hamzah B. Uno, 2009, Model Pembelajaran menciptakan proses belajar-mengajar yang kreatif dan efektif, Jakarta, Bumi Aksara, Hal. v

${ }^{3}$ Ibid, hal. vi 
dalam penulisan ini dimaksud sebagai pembelajaran dengan strategi pembelajaran Kooperatif.

Strategi pembelajaran kooperatif merupakan suatu strategi pembelajaran yang membantu peserta didik dalam mengembangkan pemahaman dan sikapnya sesuai dengan kehidupan nyata di masyarakat, sehingga dengan bekerja bersama-sama di antara sesama anggota kelompok akan meningkatkan motivasi, produktivitas, dan perolehan belajar. Strategi ini mendorong peningkatan peserta didik dalam memecahkan berbagai permasalahan yang ditemui selama pembelajaran, karena peserta didik dapat bekerja sama dengan peserta didik lain dalam menemukan dan merumuskan alternatif pemecahan tehadap masalah materi pelajaran yang dihadapi. ${ }^{4}$

Dalam pelaksanaaannya strategi kooperatif ini memanfaatkan sistem kelompok kecil didalam kelas yang terdiri dari 4 sampai 6 orang yang sebaya, kemudian mereka saling bekerja sama, berinteraksi dan bersosialisasi untuk memudahkan mereka dalam memahami materi pelajaran yang disampaikan oleh guru dengan memperhatikan keragamannya.

Sejauh mana strategi pembelajaran kooperatif ini memberikan kontribusi terhadap keberhasilan belajar siswa dibandingkan dengan strategi ekspositoris perlu dibuktikan secara empiris. Upaya untuk membuktikannya akan dilakukan dengan penelitian ekperimen yaitu membandingkan prestasi belajar dengan menggunakan strategi kooperatif dan strategi ekspositoris. Untuk mendapatkan informasi yang mendalam terhadap kontribusi yang terjadi maka ekperimen akan dikondisikan pada siswa dengan kemampuan awal tinggi maupun rendah.

\section{Metode Penelitian}

Metode penelitian yang akan digunakan adalah Penelitian Tindakan Kelas (PTK). PTK adalah penelitian yang bertujuan untuk melakukan perbaikan proses pembelajaran. PTK merupakan salah satu upaya guru atau praktisi dalam berbagai kegiatan yang dilakukan untuk memperbaiki dan atau

${ }^{4}$ Robyn M. Gillies dalam Dewi Agus Triani, Implementasi Strategi Pembelajaran Kooperatif (Cooperative Learning) Tipe Jigsaw Di Perguruan Tinggi, Universum: Jurnal Keislaman dan Kebudayaan, Vol 10, No 2 (2016), hal. 221 
meningkatkan mutu pembelajaran di kelas. ${ }^{5}$ PTK sebagai penelitian yang bersifat reflektif merupakan penelitian berupa siklus, dimana setiap siklus mempunyai beberapa tahapan. Tahapan dalam satu siklus dalam PTK adalah: Perencanaan, Pelaksanaan, Observasi dan Evaluasi, serta Refleksi dan Analisis dalam bentuk spiral.

Substansi PTK adalah perbaikan proses, dimana peneliti terlibat di dalam perbaikan proses tersebut. Terkait dengan substansi penelitian tersebut maka peranan peneliti dalam PTK adalah:

a. Sebagai katalisator,

b. Perangsang perubahan,

c. Menekankan proses dan bukan hasil,

d. Memungkinkan subjek mengembangkan sendiri analisisnya,

e. Dimulai dari subjeknya,

f. Membantu subjek menganalisis situasi mereka,

g. Memungkinkan orang menguji permasalahan mereka,

h. Tidak hanya fokus pada pemecahan masalah tetapi juga pengembangan subjek sebagai sumber daya. ${ }^{6}$

\section{Siklus Penelitian}

Siklus penelitian akan dilakukan tiga kali. Masing-masing siklus direncanakan akan menerapkan metode seperti dalam tabel implikasi metode pembelajaran student centered learning yang dimodifikasi Adapun metode yang akan digunakan dalam konsep strategi Kooperatif stad pada siklus pertama diuraikan pada siklus I, kemudian untuk menentukan metode-metode dalam konsep strategi Kooperatif stad yang akan digunakan pada siklus kedua dan ketiga tergantung pada hasil refleksi dan evaluasi siklus sebelumnya.

\footnotetext{
${ }^{5}$ Basrowi dan Suwandi, Prosedur Penelitian Tindakan Kelas, Ciawi-Bogor: PT. Ghalia Indonesia, 2008, h. 25

${ }^{6}$ Stringer, T. Ernest.. Action Researc,. Second Edition, Thousand Oaks-London: Sage Publications, 1999, h. 25-26
} 
Penelitian ini akan dilaksanakan dalam 3 siklus. Kegiatan akan diberhentikan jika telah mencapai keberhasilan yang diharapkan. Keempat kerangka utama penelitian tindakan kelas terdapat pada setiap siklus, Arikunto ${ }^{7}$ memberikan gambar sebagai berikut:

\section{Gambar 1}

Alur empat kegiatan utama dalam PTK

\section{SIKLUS I}

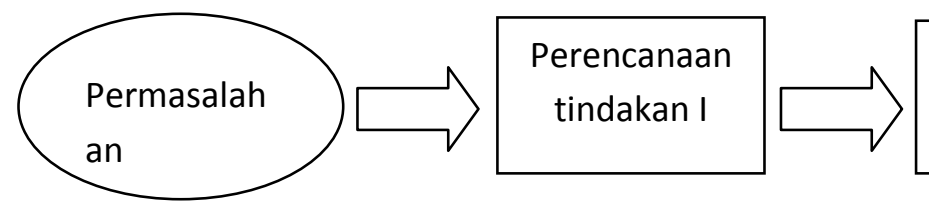

Pelaksanaan

Tindakan I

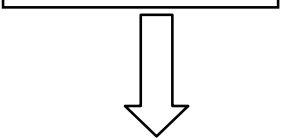

SIKLUS II
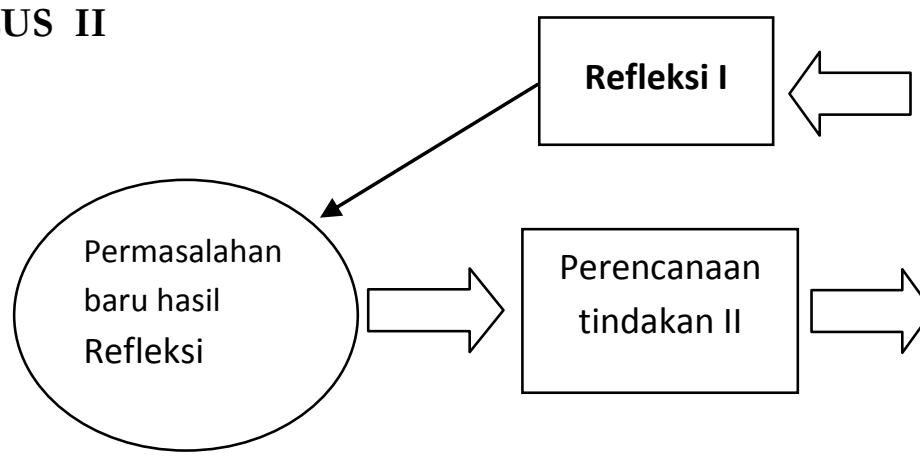

Pengamatan/ pengumpulan data
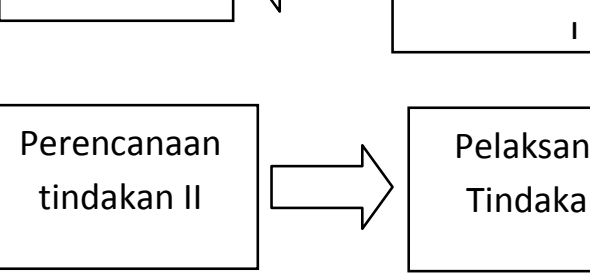

Tindakan II

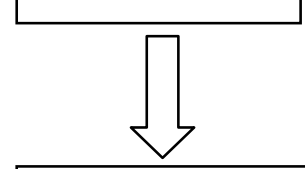

SIKLUS III

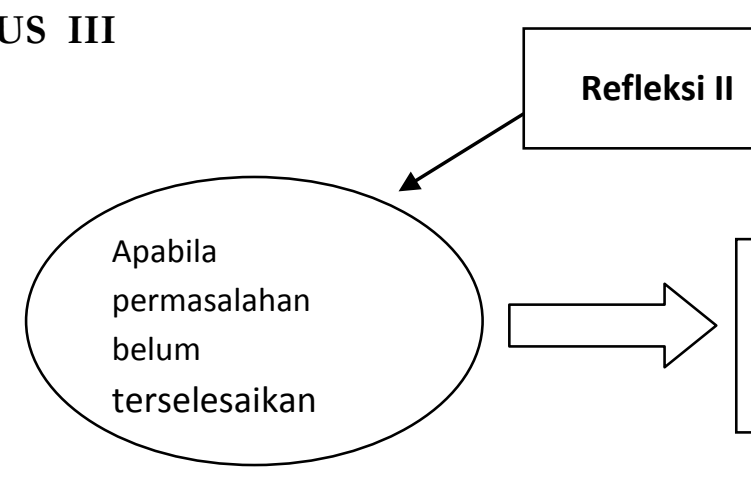

Dilanjutkan ke

Siklus berikutnya

7 Arikunto, Suharsimi, Prosedur Penelitian Suatu Pendekatan Praktik, Jakarta: Rineka Cipta, 2006, h. 74 


\section{Tempat dan waktu penelitian}

Tempat penelitian dilaksanakan di SMK Negeri1 Metro. Beralamat di Jl. Kemiri 15 A, Iring Mulyo, METRO TIMUR, KOTA METRO 34111. Waktu penelitian Dilaksanakan Pada tanggal 10 juni s/d Selesai.

\section{Teknik Analisis Data}

Analisis data bersifat kuantitatif yang telah diperoleh menggunakan statistik deskriptif. Statistik deskriptif digunakan untuk menggambarkan central tendency (ukuran pemusatan) berupa ukuran rata-rata, modus dan median dari sebaran data baik angka nominal maupun persentase. Data dianalisis secara kuantitatif, dengan cara melakukan kodifikasi hasil pengamatan ke dalam angka-angka sehingga angka-angka hasil pengolahan tersebut kembali dapat dideskripsikan.

Untuk mempermudah pemahaman data yang telah diolah tersebut ditampilkan dalam bentuk bagan atau grafik histogram. Untuk menjaga validitas data, maka instrumen tes formatif diuji validitas menggunakan metode uji validitas eksternal, karena validitas internal (validitas konstruk, konten) diperoleh melalui telaah mendalam pada proses penyusunan kisi-kisi yang dipandu dengan indikator-indikator yang telah dirumuskan dalam silabus.

Validitas eksternal pada instrumen tes dilakukan dengan cara menghitung korelasi antara skor perolehan uji coba dengan skor yang telah diperoleh siswa sebelumnya dalam materi PAI sebelumnya. Hal sesuai dengan pendapat Arikunto ${ }^{8}$ yang menyatakan bahwa "Misalnya peneliti akan mengetahui sebuah tes. Caranya adalah mencobakan tes tersebut kepada siswa yang diambil sebagai subjek uji coba. Hasil yang diperoleh kemudian dikorelasikan dengan nilai pelajaran tertentu siswa-siswa tersebut, misalnya dari nilai tes sumatif atau rapor". Karena nilai rapor tesebut dijadikan kriteria yang letaknya di luar instrumen maka menghasilkan validitas eksternal. Rumus korelasi yang digunakan adalah:

\footnotetext{
${ }^{8}$ Ibid, h. 168
} 


$$
r_{X Y}=\frac{N \sum X Y-\left(\sum X\right)\left(\sum Y\right)}{\sqrt{\left\{N \sum X^{2}-\left(\sum X\right)^{2}\right\}\left\{N \sum Y^{2}-\left(\sum Y\right)^{2}\right\}}}
$$

Keterangan:

$$
\begin{array}{ll}
r_{X Y}= & \begin{array}{l}
\text { Korelasi antara skor hasil uji coba dan skor yang ada } \\
\text { sebelumnya }
\end{array} \\
\mathrm{N}= & \text { Jumlah responden } \\
\sum X Y= & \text { Jumlah skor hasil uji coba dikalikan skor yang ada sebelumnya } \\
\sum X=\text { Jumlah skor hasil uji coba } & \text { Jumlah skor yang ada sebelumnya }
\end{array}
$$

Reliabilitas digunakan untuk menunjukkan pengertian bahwa sebuah instrumen cukup dapat dipercaya untuk digunakan sebagai alat pengumpul data. Instrumen tes selanjutnya diuji menggunakan rumus Alpha. Sebagaimana pernyataan Arikunto" "Rumus Alpha digunakan untuk mencari reliabilitas instrumen yang skornya bukan 1 dan 0 , misalnya angket atau soal bentuk uraian”. Dengan demikian rumus tepat digunakan untuk menghitung reliabilitas tes pada penelitian ini karena menggunakan soal berbentuk uraian.

Adapun rumus Alpha tersebut adalah sebagai berikut:

$r_{11}=\left(\frac{k}{(k-1)}\right)\left(1-\frac{\sum \sigma_{b}^{2}}{\sigma^{2}{ }_{1}}\right)$

$r_{11} \quad: \quad$ Reliabilitas instrumen

K : Banyaknya butir pertanyaan atau banyaknya soal

$\sum \sigma_{b}^{2}:$ Jumlah varians butir

${ }^{9}$ Ibid, h. 196 
$\sigma_{1}^{2} \quad: \quad$ Varians total

Instrumen pengamatan keterampilan proses menggunakan daftar cek. Daftar cek merupakan instrumen pengamatan. Untuk pengamatan proses hampir tidak dapat melakukan pengamatan, kecuali jika digunakan fasilitas rekaman visual. Kata kunci dari hasil pengamatan proses, bahwa perbedaan yang ditunjukan pada daftar cek tersebut haruslah sekecil mungkin. Artinya para pengamat telah mampu bersikap objek karena keterbacaan alat ukur yang baik. Teknik pengujian reliabilitas pengamatan digunakan untuk menentukan toleransi perbedaan pengamatan. Rumus yang paling banyak digunakan adalah Fernandes yang telah dimodifikasi. ${ }^{10}$ Rumus tersebut adalah sebagai berikut $K K=\frac{2 S}{N_{1}+N_{2}}$.

\section{Keterangan :}

K : Koefisien kesepakatan

S : Sepakat, jumlah kode yang sama untuk objek yang sama

$\mathrm{N}_{1} \quad$ : Jumlah kode yang dibuat pengamat I

$\mathrm{N}_{2} \quad$ : Jumlah kode yang dibuat pengamat II

Setelah melalui beberapa prosedur, rumus tersebut selanjutnya diperhalus yang dikenal dengan Indeks Kesesuaian Kasar (IKK) IKK $=\frac{n}{N}$ dengan $\mathrm{n}$ sebagai kode yang sama, dan $\mathrm{N}$ adalah banyaknya objek yang diamati. Semakin kecil nilai KK berarti intrumen pengamatan semakin reliabel.

Analisis data yang bersifat kuantitatif seperti, aktivitas selama proses pembelajaran aktivitas guru ketika membelajarkan dianalisis secara kuantitatif menggunakan metode perbandingan tetap.

\section{${ }^{10}$ Ibid, h. 197}


Kemudian untuk menjaga validitas data atau menjamin adanya keabsahan data dilakukan uji validasi menggunakan langkah-langkah:

a. Triangulasi sumber data, instrumen yang digunakan.

b. Pengecekan anggota.

c. Ketekunan pengamatan.

d. Diskusi teman sejawat.

e. Pendapat ahli, yang dalam hal ini dapat memberdayakan para pembimbing yang terlibat.

Penelitian dengan pendekatan kuantitatif menekankan analisinya pada data-data numerikal (angka) yang diolah dengan metoda statistika. Pada dasarnya, pendekatan kuantitatif dilakukan pada penelitian inferensial (dalam rangka pengujian hipotesis) dan menyandarkan kesimpulan hasilnya pada suatu probabilitas kesalahan penolakan hipotesis nihil. Dengan metoda kuantitatif akan diperoleh nilai signifikansi perbedaan kelompok atau signifikansi hubungan antar variabel yang diteliti. ${ }^{11}$

\section{Hasil Belajar}

Pengertian belajar beraneka ragam sesuai dengan aliran yang dianutnya, namun secara umum belajar itu dapat diartikan sebagai suatu proses penguasaan perubahan. Menurut Budiningsih ${ }^{12}$ dalam teori behavioristik, belajar adalah perubahan tingkah laku sebagai akibat dari adanya interaksi antara stimulus dan respon. Menurut Fontana ${ }^{13}$ belajar adalah suatu proses perubahan yang relatif tetap dalam perilaku individu sebagai hasil dari pengalaman. Senada dengan pendapat tersebut Gagne ${ }^{14}$ berpendapat bahwa belajar adalah proses yang kompleks. Lebih lanjut

${ }^{11}$ Saifuddin Azwar, Metode Penelitian, Yogyakarta, Pustaka Pelajar offset. 2015, h. 5

${ }^{12}$ Budiningsih, C. Asri, Belajar dan Pembelajaran, Jakarta: Rineka Cipta, 2005, h. 29

${ }^{13}$ Winataputra, Udin S, Teori Belajar dan Pembelajaran, Jakarta: Univeritas Terbuka, 2008, h. 8

14 Sagala, Syaiful, Konsep dan Makna Pembelajaran Untuk Membantu Memecabkan Problematika Belajar Mengajar, Alfabeta. Bandung, 2007, h. 17 
Gagnei ${ }^{15}$ menyatakan bahwa belajar terdiri dari tiga komponen penting, yaitu kondisi eksternal, kondisi internal, dan hasil belajar.

Menurut Good dan Brophy ${ }^{16}$,belajar adalah proses penguasaan perubahan secara permanen dalam pemahaman, sikap, penegtahuan, informasi, kemampuan, dan keterampilan melalui pengalaman. Menurut Fontana ${ }^{17}$ belajar adalah suatu proses perubahan yang relatif tetap dalam perilaku individu sebagai hasil dari pengalaman. Lebih lanjut Gagne ${ }^{18}$ menyatakan bahwa belajar terdiri dari tiga komponen penting, yaitu kondisi eksternal, kondisi internal, dan hasil belajar.

Hasil belajar merupakan kemampuan-kemampuan yang dimiliki siswa setelah menerima pengalaman belajar. Hasil belajar adalah kompetensikompetensi yang mampu ditunjukkan dan didemonstrasikan siswa setelah mengikuti pembelajaran. Hasil belajar kognitif berkenaan dengan hasil belajar intelektual yang terdiri dari enam aspek, yakni pengetahuan atau ingatan, pemahaman, aplikasi, analisis, sisntesis, dan evaluasi. Pengetahuan atau ingatan dan pemahaman disebut aspek kognitif tingkat rendah. Aspek aplikasi, analisis, sintesis dan evaluasi termasuk kognitif tingkat tinggi. ${ }^{19}$

Romiszowski ${ }^{20}$ menyatakan hasil belajar merupakan keluaran (out-puts) dari suatu sistem pemrosesan masukan (inputs). Masukan pada sistem tersebut bisa berbagai macam informasi sedangkan keluarannya perbuatan atau kinerja (performance). Hasil belajar sebagai keluaran dari suatu sistem pemrosesan bermacam-macam masukan yang berupa informasi, masukan yang dimaksud adalah masukan pribadi (personal input) dan masukan yang berasal dari lingkungan (evironmental inputs).

Dengan demikian hasil belajar adalah nilai yang diperoleh siswa setelah mengikuti evaluasi pembelajaran dalam kurun waktu tertentu. Hasil

${ }^{15}$ Dimyati dan Mudjiono, Belajar dan Pembelajaran, Jakarta: Rineka Cipta, 2006, h. 10

16 Departemen Pendidikan Nasional, Belajar dan Berkarya Suatu Tinjanan Psikologi Untuk Program Akseleras,. Jakarta: Dirjen Manajemen Dikdasmen Direktorat Pembinaan Pendidikan Luar Biasa, 2007, h. 8

${ }^{17}$ Winataputra, Udin S, Opcit. h.8

${ }^{18}$ Dimyati dan Mudjiono, Belajar dan Pembelajaran, Jakarta: Rineka Cipta, 2006, h. 10

${ }^{19}$ Sudjana, Nana, Penelitian dan Penilaian Pendidikan. Bandung: Sinar Baru Algensindo, 2001, h. 22

${ }^{20}$ Romiszowski, A.J. Designing Instructional System, Nichols Publishing, London, 1981, h. 217 
belajar PAI adalah kemampuan yang ditunjukkan siswa melalui penyelesaian soal-soal mata pelajaran PAI, yang digambarkan dengan skor, setelah siswa mengikuti pembelajaran PAI dalam kurun waktu tertentu.

\section{Strategi Kooperatif}

Proses pembelajaran kooperatif ini harus dapat memungkinkan sipebelajar dapat bekerja sama dengan anggota kelompoknya agar dapat mempertahankan diri dari kelompok lainnya. Kerja sama dalam kelompok tersebut memungkinkan siswa untuk mengembangkan potensinya melalui interaksi individu ke individu dan individu ke masyarakat.

Ibarat pepatah ringan sama dijinjing dan berat sama dipikul, maka sukses belajar bisa dicapai secara bersama-sama. Ini memang pepatah lama yang sering kali tak pernah serius kita resapi maknanya, apalagi mempraktekannya. Padahal, falsafah pemikiran yang tersirat dalam pantun ini, kini menjadi salah pendekatan yang gencar dikampanyekan di AS. Universitas Minnesota adalah universitas pertama yang mengembangkan pendekatan belajar ini. Bahkan secara khusus universitas ini telah mendirikan Pusat Belajar Kooperatif (Cooperative Learning Centre/CLC) yang dikelola oleh Profesor Roger T. Johnson, seorang pakar pendidikan sains dan David W. Johnson, pakar psikologi pendidikan. Kedua orang inilah yang sejak tahun 1960an gemar mencari pendekatan baru belajar secara efektif. ${ }^{21}$

Pembelajaran kooperatif mengandung elemen-elemen:

a. Clearly perceived positive interdependence (adanya ketergantungan positif),

b. Consi-derable promotive (face-to-face) interaction (meningkatkan interaksi tatap muka individu),

c. Clearly perceived individual accountability and personal responsibility to achieve the group's goals (adanya kepercayaan dan tanggung jawab pribadi dalam mencapai tujuan kelompok),

${ }^{21}$ Tempo, Koran, Belajar Kooperatif, 2008, http://www.korantempo.com/ news/ 2002/1/13/Belajar/4.html, (Diakses pukul 11.30 WIB, 12 Juni 2018) 
d. Frequent use of the relevant interpersonal and small-group skills (seringnya digunakan keteram-pilan berhubungan antar pribadi dan kelompok kecil), dan

e. Frequent and regular group processing of current functioning to improve the group's future effectiveness (proses pemberdayaan kelompok dengan sering dan teratur untuk mengembangkan keefektifan masa depan kelompok).

\section{Kooperatif Tipe STAD}

Terdapat sedikitnya tiga macam strategi pembelajaran kooperatif yang dapat digunakan dan dikembangkan pada semua tingkatan yaitu:

a. Students Team Achievement Division (STAD),

b. Team Games Tournament, dan

c. Jig Saw.

Strategi pembelajaran kooperatif model STAD dipilih untuk penelitian ini, karena strategi ini secara konsep dan keterampilan dirasa dapat meningkatkan dan menguatkan hasil belajar sekaligus setrategi ini merupakan strategi pengelompokkan siswa yang sederhana.

\section{Langkah-Langkah Pembelajaran Strategi Kooperatif Model STAD}

Pada dasarnya penyampaian strategi kooperatif STAD dibagi menjadi dua bagian utama yaitu:

a. Presentasi dari guru.

b. Inisiasi dan monitoring dari guru terhadap kerja tim.

Langkah dalam pelaksanaan strategi kooperatif model STAD adalah sebagai berikut: Pertama, persiapan penelitian yang meliputi:

a. Penentuan bahan/materi ajar sesuai dengan SK dan KD yang akan dibahas dalam penelitian ini, membuat lembar kerja siswa, dan kuis untuk setiap KD

b. Membentuk kelompok secara acak 
c. Menentukan skor dasar awal melalui pre tes.

Kedua, Penyajian pelajaran. Penyajian pelajaran dalam STAD melibatkan ceramah, penunjukkan dengan menggunakan slide pada OHP, atau pengarahan pada sumber-sumber belajar seperti teks dan bacaan. Namun yang paling sering adalah dilakukan direct instruction atau pembelajaran langsung, ceramah dan diskusi untuk menjelaskan tujuan dan materi bahan pelajaran serta fokus pemahaman yang diharapkan.

Ketiga, Kerja kelompok merupakan ciri yang paling penting dalam STAD dan merupakan kegiatan utama yang bertujuan agar siswa belajar bersama dalam memahami materi. Setelah guru selesai menyajikan materinya, kelompok bertemu untuk mengkaji lembar kerja atau materi yang lain. Sering kali pengkajian ini melibatkan siswa untuk mendiskusikan soal-soal secara bersama-sama, membandingkan jawaban, dan memperbaiki adanya kesalahpahaman jika ada anggota kelompok yang membuat kesalahan. Supaya kerja kelompok tersebut menjadi efektif, maka siswa perlu diberi seperangkat pertanyaan, lembar kerja atau materi lain untuk membimbing diskusinya.

Keempat, Kuis. Kuis ini mencakup latihan mandiri (tes) dan penilaian (evaluasi). Setelah periode presentasi guru dan kerja kelompok, siswa mengikuti kuis. Siswa tidak boleh saling membantu selama kuis. Setiap siswa bertanggung jawab secara individu menguasai materi. Penilaian kuis berdasarkan atas skor individu. Ide dibalik skor peningkatan individu ini adalah untuk memberikan kepada setiap siswa tujuan berprestasi, yang dapat ia peroleh ketika bekerja keras serta menjadi lebih baik pada masa lalu.

Kelima, penghargaan kelompok. Kelompok memperoleh penghargaan jika skor rata-ratanya memnuhi kriteria yang telah ditentukan. Salah satu bentuk penghargaan ini adalah bisa berupa nilai tambahan. Nilai tambahan bisa diberikan kepada semua anggota kelompok yang rata-rata skor yang diperolehnya tertinggi dari kelompok lain. Penghargaan bisa dibuat berjenjang: terbaik, kedua dan ketiga. Cara lain dari penghargaan tersebut adalah dengan memberikan pujian kepada kelompok yang terbaik.

\section{Hasil Penelitian}


Sehubungan penelitian yang dilakukan merupakan penelitian tindakan kelas, analisis data dilakukan secara terus menerus selama penelitian berlangsung. Setelah data terkumpul dilakukan analisis kualitatif terhadap unsur-unsur atau faktor-faktor yang terkait dalam proses pembelajaran, mulai dari tahap perencanaan, pelaksanaan, observasi sampai dengan refleksi untuk setiap siklus dan untuk setiap sekolah (karena penelitian ini dilangsungkan untuk SMK Negeri 1 Metro. Data yang dikuantitatifkan dianalisis dengan prosentase dan diinterpretasikan (pemaknaan) untuk memperoleh gambaran mengenai hasil penelitian yang dilakukan. Setiap temuan dalam data penelitian diinterpretasikan dengan mengacu pada teori yang ada dan ketentuan praktis yang telah disepakati agar lebih baik pada proses pembelajaran berikutnya.

Penelitian ini direncanakan sebanyak tiga siklus, setiap siklus terdiri dari 4 tahap, yaitu perencanaan, pelaksanaan, observasi dan refleksi. Setiap siklus berlangsung selama 2 x 40 menit. Unsur yang diamati adalah:

1. Keberadaan RPP yang relevan dalam mengembangkan penggunaan strategi Kooperatif STAD

2. Keterlaksanaan proses pembelajaran yang sesuai dengan perencanaan dalam strategi pembelajaran

3. Tes formatif dan hasil pengamatan terhadap pelaksanaan praktik penggunaan strategi kooperatif. Indikator keberhasilan ditunjukan pada tabel di bawah ini.

\section{Tabel 1}

Indikator Keberhasilan

\begin{tabular}{|c|c|c|c|c|}
\hline Tujuan penelitian & Instrumen & \multicolumn{3}{|c|}{ Indikator Keberhasilan } \\
\hline tentang: & digunakan & Siklus I & Siklus II & Siklus III \\
\hline $\begin{array}{l}\text { perencanaan } \\
\text { pembelajaran PAI } \\
\text { dengan } \\
\text { menggunakan } \\
\text { strategi kooperatif }\end{array}$ & $\begin{array}{l}\text { Daftar cek } \\
\text { perencanaan } \\
\text { pembelajaran }\end{array}$ & $\begin{array}{l}\text { Menunjukan } \\
\text { skor } \\
\text { perencanaan } \\
\text { pembelajaran } \\
75 \%\end{array}$ & $\begin{array}{l}\text { Menunjukan } \\
\text { skor } \\
\text { perencanaan } \\
\text { pembelajaran } \\
80 \%\end{array}$ & $\begin{array}{l}\text { Menunjukan } \\
\text { skor } \\
\text { perencanaan } \\
\text { pembelajaran } \\
85 \%\end{array}$ \\
\hline
\end{tabular}




\begin{tabular}{|c|c|c|c|c|}
\hline $\begin{array}{l}\text { pelaksanaan } \\
\text { pembelajaran PAI } \\
\text { dengan } \\
\text { menggunakan } \\
\text { strategi kooperatif }\end{array}$ & $\begin{array}{l}\text { Daftar cek } \\
\text { aktivitas guru }\end{array}$ & $\begin{array}{l}\text { Menunjukan } \\
\text { skor aktivitas } \\
\text { guru } 65 \%\end{array}$ & $\begin{array}{l}\text { Menunjukan } \\
\text { skor aktivitas } \\
\text { guru } \\
70 \%\end{array}$ & $\begin{array}{l}\text { Menunjukan } \\
\text { skor aktivitas } \\
\text { guru } \\
75 \%\end{array}$ \\
\hline $\begin{array}{l}\text { pelaksanaan } \\
\text { evaluasi } \\
\text { pembelajaran } \\
\text { menggunakan } \\
\text { strategi kooperatif }\end{array}$ & $\begin{array}{l}\text { Daftar cek } \\
\text { aktivitas siwa }\end{array}$ & $\begin{array}{l}\text { Menunjukan } \\
\text { skor aktivitas } \\
\text { siswa } 70 \%\end{array}$ & $\begin{array}{l}\text { Menunjukan } \\
\text { skor aktivitas } \\
\text { siswa } \\
75 \%\end{array}$ & $\begin{array}{l}\text { Menunjukan } \\
\text { skor aktivitas } \\
\text { siswa } \\
80 \%\end{array}$ \\
\hline $\begin{array}{l}\text { perolehan prestasi } \\
\text { belajar siswa dalam } \\
\text { mata pelajaran PAI }\end{array}$ & Tes Formatif & $\begin{array}{l}\text { Menunjukan } \\
\text { skor tes } \\
\text { formatif } \\
\text { LKS } 65 \%\end{array}$ & $\begin{array}{l}\text { Menunjukan } \\
\text { skor tes } \\
\text { formatif } \\
70 \%\end{array}$ & $\begin{array}{l}\text { Menunjukan } \\
\text { skor tes } \\
\text { formatif } 75 \%\end{array}$ \\
\hline
\end{tabular}

Data persentase dari siklus I, II, dan III selanjutnya dikumpulkan untuk dibandingkan. Perbandingan tersebut dimaksudkan untuk melihat adanya peningkatan yang terjadi dari masing-masing siklus. Peningkatan tiap aspek dapat dilihat pada gambar di bawah ini.

Gambar 2

Perbandingan Persentase Aktivitas Guru Siklus I, II \& III

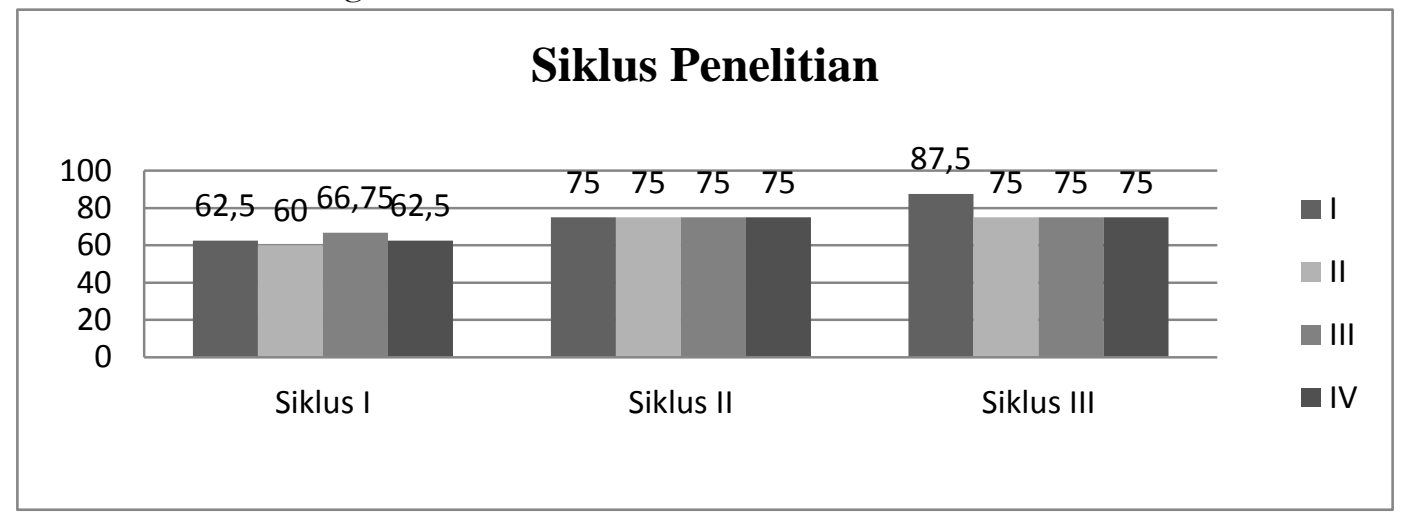

Gambaran secara keseluruhan mengenai aktivitas guru selama proses pembelajaran dari siklus I, II dan III perlu diperoleh untuk memberikan 
adanya peningkatan yang linier. Cara yang digunakan adalah dengan menghitung rata-rata persentase masing-masing pada tiap siklus. Gambaran tersebut selanjutnya dapat dilihat pada Gambar berikut ini.

\section{Gambar 3}

Perbandingan Rata-rata Skor Aktivitas Guru pada Siklus I, II, dan III

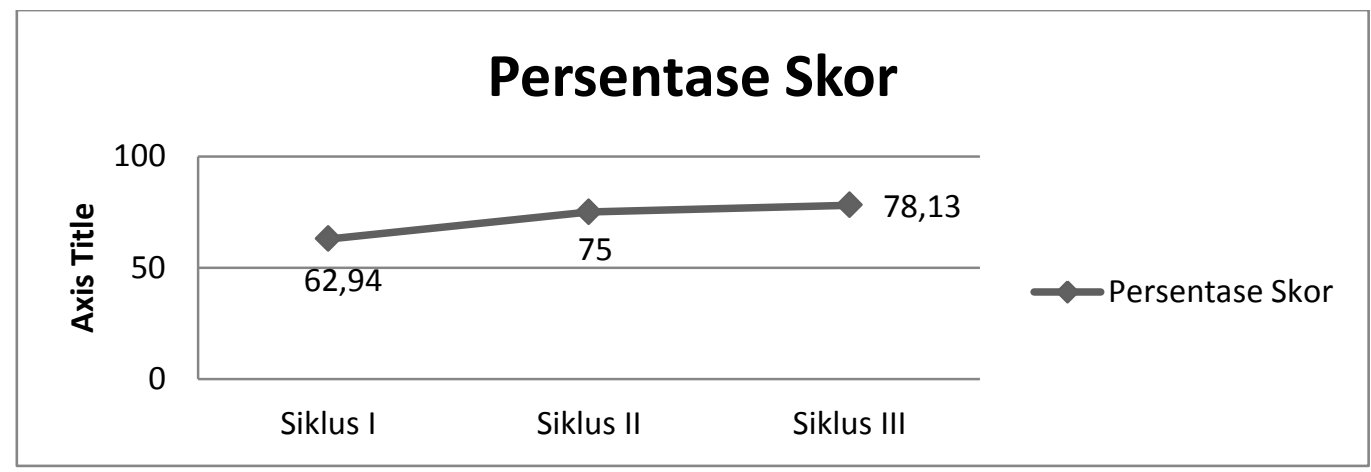

Berdasarkan Gambar di atas dapat dinyatakan terdapat peningkatan aktivitas guru selama proses pembelajaran dari siklus I ke siklus II, sebesar $12.06 \%(62,94-75)$ sedangkan dari siklus II ke siklus III peningkatan hanya terjadi sebesar $3.13 \%$.

Selanjutnya keseluruhan data dari siklus I, II, dan III dihitungan ratarata sehingga diperoleh rata-rata. Data tersebut kemudian dibandingkan sebagai berikut:

\section{Tabel 2}

Rekap Rata-rata Evaluasi Pembelajaran Siklus I, II, dan III

\begin{tabular}{llrrr}
\hline No & \multicolumn{1}{c}{ Aspek } & \multicolumn{2}{c}{ SMK Negeri 1 Metro } \\
& & Siklus I & \multicolumn{1}{c}{ Siklus II } & \multicolumn{1}{c}{ Siklus III } \\
1 & Identitas & 54.17 & 66.67 & 75 \\
2 & Indikator & 75 & 75 & 87.5 \\
3 & Tujuan Pembelajaran & 62.5 & 62.5 & 100 \\
4 & Materi Pembelajaran & 62.5 & 62.5 & 100 \\
5 & Metode Pembelajaran & 50 & 62.5 & 75 \\
6 & Kegiatan & 50 & 56.25 & 81.25 \\
& Pembelajaran & & & \\
& & &
\end{tabular}




\begin{tabular}{llrrr}
\hline 7 & Alat dan Bahan & 62.5 & 62.5 & 100 \\
& Rata-rata Persentase & 59.52 & 63.99 & 88.39 \\
\hline
\end{tabular}

Perbandingan rata-rata persentase evaluasi pembelajaran tiap siklus selanjutnya ditampilkan pada gambar di bawah ini.

\section{Gambar 4}

Peningkatan Rata-rata Persentase Evaluasi Pembelajaran Siklus I, II, dan III

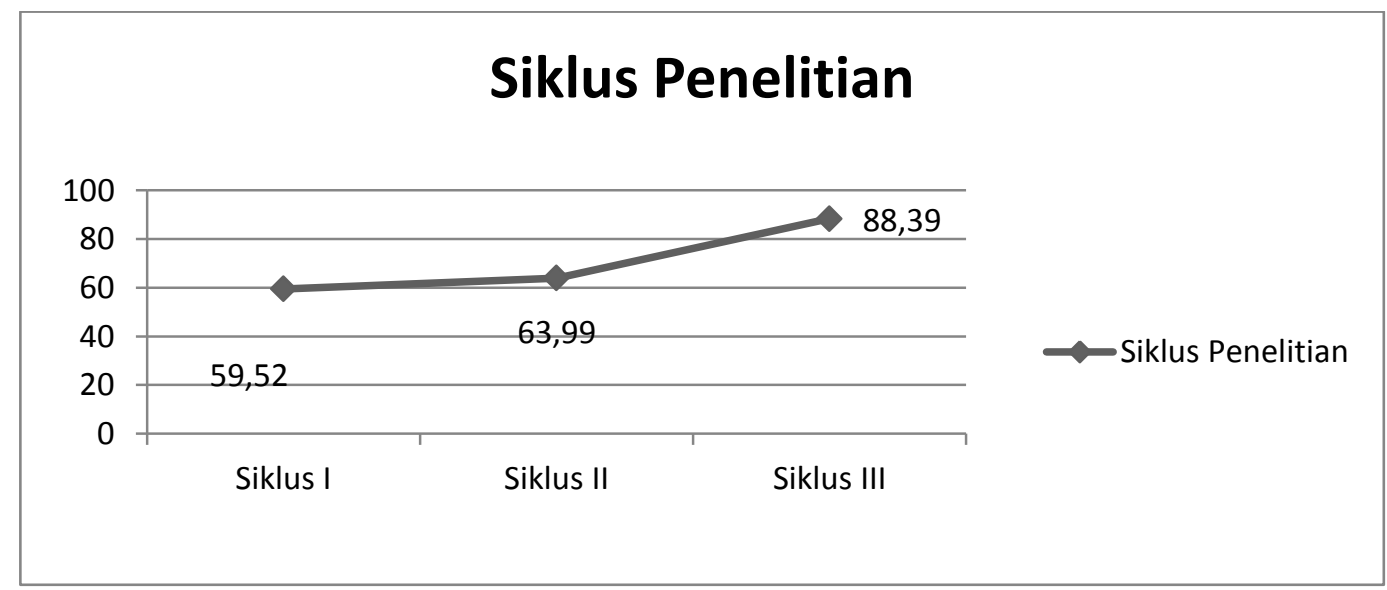

Secara komulatif, peningkatan tersebut dapat dijelaskan sebagai berikut:

a) Dari siklus I ke II terjadi peningkatan sebesar 4,47\% (59,52-63,99).

b) Dari siklus II ke III terjadi peningkatan sebesar 24,40\% $(63,99-88,39)$.

Gambaran peningkatan rata-rata skor tes formatif dari siklus I, II dan III selanjutnya ditampilkan pada Gambar 23 di bawah ini.

\section{Gambar 5}

Peningkatan Rata-rata Skor Tes Formatif SMK Negeri 1 Metro tiap Siklus 


\section{Siklus Penelitian}

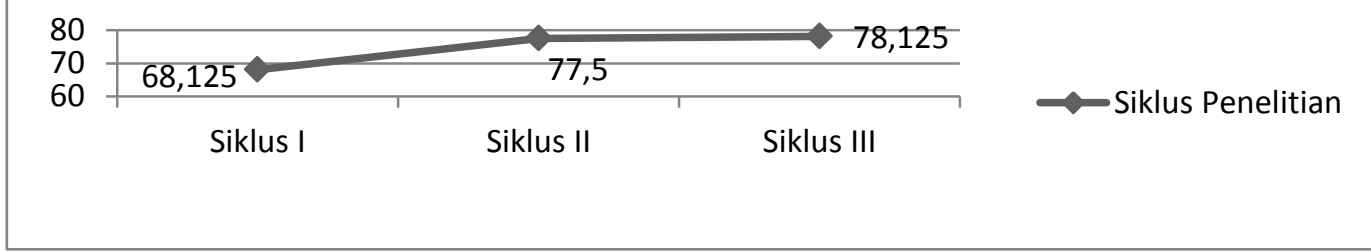

Berdasarkan gambar diatas menunjukan adanya peningkatan skor tes formatif yang signifikan dari siklus I ke II. Peningkatan tersebut terjadi pada kisaran 10 poin.

Namun setelah dilanjutkan dari siklus II ke III rata-rata skor tetap tinggi yaitu pada kisaran rata-rata skor 778.1257, tidak ada peningkatan signifikan yang ditunjukan subjek penelitian setelah diberi perlakuan siklus III (rata-rata tesnya tetap).

\section{Observasi}

\section{1) Data Aktivitas Guru}

Terdapat peningkatan aktivitas guru selama proses pembelajaran dari siklus I ke siklus II, sebesar $12.06 \%(62,94-75)$ sedangkan dari siklus II ke siklus III peningkatan hanya terjadi sebesar 3.13\%. Aktivitas guru pada siklus III ini tetap berada pada kategori tinggi.

Peningkatan yang ditunjukan dari siklus I ke II, merupakan dampak dari hasil evaluasi aktivitas guru dalam pembelajaran. Peningkatan yang terjadi telah mencapai indikator pencapaian yaitu skor persentase $70 \%$, namun pada siklus III ada peningkatan tetapi tidak signifikan. Hal ini terjadi karena tindakan yang diberikan sudah tidak lagi mampu memberikan perbaikan pada aktivitas guru dalam pembelajaran. Dengan kata lain, pada siklus III ini telah terjadi kejenuhan pada aktivitas guru.

\section{2) Data Aktivitas Siswa}

Gambar 23 menunjukan bahwa rata-rata persentase skor tertinggi terdapat pada unsur C, yaitu komunikasi yang terdiri dari: 
a) Menyampaikan usul/pendapat.

b) Menghargai pendapat.

c) Penyampaian laporan.

Kelompok dengan skor tertinggi adalah kelompok IV. Kecuali pada kelompok III, skor aspek B dan C adalah sama. Rata-rata skor jumlah, tiga kelompok (I, II, IV) pada siklus II berada di atas skor 75,5, 75,9, 75,8. Terdapat dua kelompok (III, V) yang turun sedikit dari skor 75\% (73,1\% dan 74,6\%). Artinya kelompok tersebut mempunyai aktivitas yang tinggi. Pada siklus III kelompok I, II, IV dan V berada pada skor 75,5\%, hanya satu kelompok (III) turun pada skor 71,3\%. Jumlah skor di bawah 75\% dinyatakan aktivitas rendah, kemudian $\geq 75 \%$ dinyatakan tinggi, maka pada siklus III aktivitas siswa saat proses pembelajaran masih tetap tinggi.

\section{1) Perencanaan Pembelajaran}

Secara kumulatif, dengan menggunakan rata-rata persentase, peningkatan yang terjadi pada pada tiap-tiap siklus dapat dijelaskan, dari siklus I ke II terjadi peningkatan sebesar 4,47\% (59,52-63,99); dari siklus II ke III terjadi peningkatan sebesar $24,40 \%(63,99-88,39)$.

Indikator pencapai evaluasi perencanaan pembelajaran pada siklus III adalah pencapaian sebesar 85\%. Pada presentase skor terakhir adalah 88,39 dengan demikian maka telah melebihi indikator pencapaian yang direncanakan. Melihat keadaan ini maka siklus dihentikan sampai pada siklus III karena telah mencapai indikator pencapaian.

\section{2) Data Tes Formatif}

Peningkatan yang signifikan dari tes formatif terjadi dari siklus I ke II. Peningkatan tersebut terjadi pada kisaran 10 poin. Setelah dilanjutkan dari siklus II ke III rata-rata skor tetap tinggi yaitu pada kisaran rata-rata skor 77, namun tidak ada peningkatan yang signifikan yang ditunjukan oleh subjek penelitian setelah diberi perlakuan siklus III.

Dengan kata lain bahwa rata-rata tes formatif adalah tetap. Beberapa siswa mendapatkan nilai 100 pada siklus III. Hal ini menunjukkan bahwa penggunaan strategi kooperatif memberikan peluang pengembangan potensi 
individu secara individual, dan telah melebihi indikator pencapaian pada skor 75.

\section{Keterbatasan Penelitian}

Beberapa keterbatasan yang terdapat dalam penelitian ini adalah:

1) Guru masih kurang memberdayakan peran aktif siswa, sehingga peran guru masih mendominasi, khususnya pada siklus pertama, hal ini terkait dengan kebiasaan siswa yang selama ini dalam pembelajaran mereka biasa dituntun terus menggunakan metode ceramah.

2) Lemahnya pemahaman guru tentang penerapan fungsi sebagai fasilitator.

\section{Kesimpulan}

Berdasarkan uraian sebelunya, disimpulkan bahwa hasil belajar PAI dapat ditingkatkan melalui strategi kooperatif. Hal ini berdasarkan temuan:

1. Perencanaan pembelajaran PAI dengan menggunakan strategi kooperatif dapat dilaksanakan dengan baik. Pembelajaran menggunakan strategi kooperatif mengalami peningkatan dari siklus I ke II sebesar 4,47\% $(59,52-63,99)$ dari siklus II ke III terjadi peningkatan sebesar $24,40 \%$ $(63,99-88,39)$. Indikator pencapai evaluasi perencanaan pembelajaran pada siklus III adalah pencapaian sebesar $85 \%$. Peresentase skor terakhir adalah 88,39. Dengan demikian keduanya telah melebihi indikator pencapaian yang direncanakan. Begitu pula dengan Pelaksanaan pembelajaran PAI dengan menggunakan media strategi kooperatif juga berjalan dengan baik, dalam hal ini terdapat peningkatan aktivitas guru pada SMK Negeri 1 selama proses pembelajaran dari siklus I ke siklus II, sebesar $12.06 \%$ (62,94-75) sedangkan dari siklus II ke siklus III peningkatan hanya terjadi sebesar 3.13\%. Peningkatan yang terjadi merupakan peningkatan yang signifikan. Aktivitas guru pada siklus III ini tetap berada pada kategori tinggi.

2. Pelaksanaan evaluasi pembelajaran yang diukur dengan aktivitas siswa dan penilaian rata-rata skor jumlah tiga kelompok (I, II, IV) pada siklus II berada di atas skor 75,5, 75,9, 75,8. Terdapat dua kelompok (III, V) yang turun sedikit dari skor 75\% (73,1\% dan 74,6\%). Artinya kelompok 
tersebut mempunyai aktivitas yang tinggi. Pada siklus III kelompok I, II, IV dan V berada pada skor 75,5\%, hanya satu kelompok (III) turun pada skor $71,3 \%$. Pada siklus III aktivitas siswa saat proses pembelajaran masih tetap tinggi. Sementara Peningkatan yang signifikan dari tes formatif terjadi dari siklus I ke II. Peningkatan tersebut terjadi pada kisaran 10 poin. Setelah dilanjutkan dari siklus II ke III rata-rata skor tetap tinggi yaitu pada kisaran rata-rata skor 77 , namun tidak ada peningkatan yang signifikan yang ditunjukan oleh subjek penelitian setelah diberi perlakuan siklus III. Dengan kata lain bahwa rata-rata tes formatif adalah tetap. Beberapa siswa mendapatkan nilai 100 pada siklus III. Hal ini menunjukkan bahwa penggunaan media kooperatif memberikan peluang pengembangan potensi individu secara individual, dan telah melebihi indikator pencapaian pada skor 75 .

Perolehan prestasi belajar PAI meningkat seiring dengan peningkatan perencanaan pembelajaran, pelaksanaan pembelajaran, dan pelaksanaan evaluasi pembelajaran dengan menggunakan strategi kooperatif. Dengan demikian implikasi penelitian tindakan ini adalah perencanaan pembelajaran, pelaksanaan pembelajaran, dan pelaksanaan evaluasi pembelajaran dengan menggunakan strategi kooperatif harus dikondisikan sedemikian secara konsisten.

\section{DAFTAR PUSTAKA}

Arikunto, Suharsimi, Prosedur Penelitian Suatu Pendekatan Praktik, Jakarta: Rineka Cipta, 2006

Basrowi dan Suwandi, Prosedur Penelitian Tindakan Kelas, Ciawi-Bogor: PT. Ghalia Indonesia, 2008,

Budiningsih, C. Asri, Belajar dan Pembelajaran, Jakarta: Rineka Cipta, 2005

Departemen Pendidikan Nasional, Belajar dan Berkarya Suatu Tinjauan Psikologi

Untuk Program Akseleras,. Jakarta: Dirjen Manajemen Dikdasmen

Direktorat Pembinaan Pendidikan Luar Biasa, 2007

Dimyati dan Mudjiono, Belajar dan Pembelajaran, Jakarta: Rineka Cipta, 2006

Hamzah B. Uno, Model Pembelajaran menciptakan proses belajar-mengajar yang kreatif dan efektif, Jakarta, Bumi Aksara, 2009 
Robyn M. Gillies dalam Dewi Agus Triani, Implementasi Strategi Pembelajaran Kooperatif (Cooperative Learning) Tipe Jigsaw Di Perguruan Tinggi, Universum: Jurnal Keislaman dan Kebudayaan, Vol 10, No 2 (2016) Romiszowski, A.J. Designing Instructional System, Nichols Publishing, London, 1981Tempo, Koran, Belajar Kooperatif, 2008, http://www.korantempo.com/ news/ 2002/1/13/Belajar/4.html, (Diakses pukul 11.30 WIB, 12 Juni 2018)

Sagala, Syaiful, Konsep dan Makna Pembelajaran Untuk Membantu Memecabkan Problematika Belajar Mengajar, Alfabeta. Bandung, 2007

Saifuddin Azwar, Metode Penelitian, Yogyakarta, Pustaka Pelajar offset. 2015

Stringer, T. Ernest.. Action Researc,. Second Edition, Thousand Oaks-London: Sage Publications, 1999

Sudjana, Nana, Penelitian dan Penilaian Pendidikan. Bandung : Sinar Baru Algensindo, 2001

Sugiyono, Memahami Penelitian Kualitatif. Bandung: Alfabeta, 2005

Suyadi, Teori Pembelajaran Anak Usia Dini dalam Kajian Neurosains, Bandung. Pt. Remaja Rosdakarya, 2015

Winataputra, Udin S, Teori Belajar dan Pembelajaran, Jakarta: Univeritas Terbuka, 2008 